\title{
Mercury isotope compositions in Upper Mekong and Salween rivers on the Tibetan Plateau
}

\author{
SHENG HE ${ }^{1}$ AND JIUBIN CHEN ${ }^{2}$
}

${ }^{1}$ Institute of Surface-Earth System Science, School of Earth System Science, Tianjin University

${ }^{2}$ Tianjin University

Presenting Author: shenghe@tju.edu.cn

Glaciers in Tibetan Plateau (TP), known as the "Third Pole", are melting dramatically due to climate change. Contaminants stored in glaciers like mercury $(\mathrm{Hg})$ are released to aquatic systems, which supply water resources to people living downstream. Thus, it's crucial to constrain source and transformation of $\mathrm{Hg}$ in $\mathrm{TP}$ glacierized mountain rivers. However, few studies in TP were carried out. $\mathrm{Hg}$ isotopes would help for tracing $\mathrm{Hg}$ in the high plateau aquatic systems.

Here we reported $\mathrm{Hg}$ isotope compositions in waters of two adjacent high TP rivers, the Upper Salween River and Upper Mekong River, of which the glaciers cover different area (of $1.3 \%$ and $0.2 \%$ over the whole catchment, respectively). Significantly positive $\Delta^{199} \mathrm{Hg} \quad(0.45 \%$ o to $3.12 \%)$ were determined in Upper Salween River, while the Upper Mekong River samples showed negative to slightly positive $\Delta^{199} \mathrm{Hg}$ $\left(-0.42 \%\right.$ to $0.61 \%$ ). Both rivers displayed a $\Delta^{199} \mathrm{Hg} / \Delta^{201} \mathrm{Hg}$ slope close to 1 , indicating odd-MIF was produced by photoreduction of inorganic $\mathrm{Hg}$ (II). Considering the significantly positive odd-MIF found in TP glacier and different glacierized areas of two watersheds, we suggest $\mathrm{Hg}$ released from glacier could be an important source for stream waters in glacierized mountain area, explaining the higher $\Delta^{199} \mathrm{Hg}$ values (up to 3\%o) in the Salween River. In addition, the geological and atmospheric deposition would also contribute to $\mathrm{Hg}$ budgets in these rivers. Therefore, our finding reveals dissolved $\mathrm{Hg}$ released from glacier plays a critical role in the biogeochemical cycle of $\mathrm{Hg}$ in TP mountain regions, and emphasizes the importance of studying the impact of climate change on $\mathrm{Hg}$ budget in glacierized areas. 